\title{
Hyaluronate Increases Polynucleotides Effect on Human Cultured Fibroblasts
}

\author{
Stefano Guizzardi ${ }^{1}$, Jacopo Uggeri ${ }^{1}$, Silvana Belletti $^{1}$, Giulia Cattarini $^{2}$ \\ ${ }^{1}$ Department of Biomedical Biological and Tranlational Sciences (S.Bi.Bi.T.), University of Parma, Parma, Italy; ${ }^{2}$ Mastelli Research \\ Lab, Sanremo, Italy. \\ Email: stefano.guizzardi@unipr.it
}

Received February $6^{\text {th }}, 2013$; revised March $1^{\text {st }}, 2013$; accepted March $8^{\text {th }}, 2013$

\begin{abstract}
The HA is present in almost all vertebrates and plays a critical role in tissue development and cell proliferation, it has been demonstrated to promote wound healing and involved in angiogenesis and inflammation. Also polynucleotydes (PN) have proved to promote the "in vitro" growth and activity of human fibroblasts and osteoblasts, to increase reparation on UVB damaged dermal fibroblasts and seems to promote proliferation of human pre-adipocytes. Several in vivo studies have demonstrated the PN effect also in vivo, inducing an increase of angiogenesis and healing process. In this paper we have evaluated the effect of a mixture of Polynucleotides (PN) and entire Hyaluronic Acid (HA) on cultured human fibroblasts by analyzing cell growth. Different mixture have been tested and it has been demonstrated that the presence of HA even at low concentration $(1 \mathrm{mg} / \mathrm{ml})$ determine an increase of PN activity up to $20 \%$. Furthermore, the addition of $\mathrm{HA} 1 \mathrm{mg} / \mathrm{ml}$ to PN $100 \mu \mathrm{g} / \mathrm{ml}$ induces a cell growth rate comparable to that exerted by PN concentration of $12 \mu \mathrm{g} / \mathrm{ml}$.
\end{abstract}

Keywords: Polynucleotides; Fibroblasts; Hyaluronate; Dermal Regeneration

\section{Introduction}

Large body of evidence supports the concept of critical role of microenvironment in cell behavior, in fact the area around cells plays an important action in normal tissues, regulating growth factor concentration, nutrients supply and maintaining an intense cross-talk between cells. During the tissue development, this carefully organized microenvironment changes its functions' modifying specifically. Microenvironment is a complex structure constituted by a milieu of molecules accounting proteins as collagens, fibronectin, elastin, DNA fragments and complex polysaccharides as proteoglycans and hyaluronan (HA).

A source of DNA fragments may be considered Polydeoxyribonucleotide (PN). PN is a compound that, acting through adenosine receptors, determines different effects on mesenkymal derived cells. Thellung e coll and Sini e coll $[1,2]$ firstly have demonstrated that PN enhance pro-liferation of human fibroblasts and the involvement of purinergic A2 receptors. Some other authors have studied the effect of PN both in in vitro and in vivo: PN have been demonstrated to promote the growth of human corneal fibroblasts [3] and osteoblasts [4], to increase reparation on UVB damaged dermal fibroblasts [5] and seems to promote proliferation of human pre-adipocytes
[6]. Numerous in vivo studies have demonstrated the PDRN effect on patients undergoing skin explants [7] or a fast corneal epithelisation after photorefractive keratotomy [8]. PN have been also tested in osteorepair $[9,10]$, demonstrating an increase of healing process. Finally polynucleotide has been demonstrated to stimulated wound healing and angiogenesis inducing an increase of VEGF production during pathologic conditions of low tissue perfusion such as diabetes mellitus and thermal injury [11-13].

$\mathrm{PN}$ is the active fraction of a preparation used in therapy as an agent to stimulate tissue repair and is extracted from the sperm of trout bred for human consumption.

The drug is obtained by an extraction process with purifying and high temperature sterilizing procedures to obtain a $95 \%$ pure active principle without pharmacologically active proteins and peptides. This compound holds a mixture of deoxyribonucleotides polymers with chain lengths ranging between 50 and $2000 \mathrm{bp}$ and may also represent the source of purine and pyrimidine deoxynucleosides/deoxyribonucleotides and bases.

$\mathrm{HA}$ is present in almost all vertebrates and plays a critical role in tissue development and cell proliferation [14]. HA is a non sulphated and non branched polysaccharide, constituted by thousand of disaccharide units (it 
contains up to 25,000 disaccharide units of glucuronic acid and N-Acetil-glucosamine), reaching million Daltons in weight. Hyaluronan is important in tissue development and repair, it regulates water content and molecular trafficking forming a gel with specific viscoelastic properties. The discovery of several HA cell receptors and several interactions of this polymer with other extracellular molecules, including the role of hyaluronan oligos in inflammation and angiogenesis, induced the scientific community to reconsider the biological role of this polysaccharide. HA is produced by cells throughout the activity of three Hyaluronic Acid Synthases (HAS1, 2 and 3), membrane enzymes which produce the polymer extruding the chain through the cell membranes. Extrusion of the growing HA chain extracellularly through the plasma membrane permits unrestrained growth of the polymer, so that it can reach $1000-10,000 \mathrm{kDa}$. Synthesis of such an enormous polymer could not be possible intracellularly.

The question why cell have three different enzymes for the hyaluronan synthesis is still unknown. The threemember HAS isoenzyme family, localized to three separate chromosomes, was identified in human and mouse genomes [15]. Sequence data indicate that there are seven transmembrane regions, and that a central cytoplasmic domain contains consensus sequences that are substrates for phosphorylation by protein kinase C [16].

HAS2 is also implicated in developmental and repair processes involving tissue expansion and growth. HAS3 is the most active HAS enzyme, and drives the synthesis of large amounts of lower MW HA chains. The products of HAS3 may provide the pericellular glycocalyx and the HA that interacts with cell surface receptors. Such shorter HA chains may trigger cascades of signal transduction events and major changes in cellular behaviour [17]. Our studies suggested that the enzymes have different metabolic regulation as well as produce polymers with different size (HAS2 produces HA of large size and HAS3 small size, HAS1 is active mainly in fetal stage). HAS2 and HAS3 are differently expressed in cancer cell lines, and it was reported that HAS2 is more often related to aggressive cancer and HAS3 to the less invasive form of tumors [18]. Nevertheless the overexpression of HAS2 reduces the tumor growth maybe affecting the energy availability of the cells [16]. HAS1-3 siRNA reduced the cell motility in ovarian tumor cell lines altering cytoskeleton framework.

Hyaluronan's high capacity for holding water and high viscoelasticity give it a unique profile among biological materials and make it suitable for various medical and pharmaceutical applications. We can find a variety of hyaluronan products in our daily life. For example, because it retains moisture, hyaluronan is used in some cosmetics to keep skin young and freshlooking. Even though hyaluronan is abundant in skin, as we age, the waterholding ability of our skin's hyaluronan is reduced by depolymerization.

It is well recognized that there is an early accumulation of HA in the wounded tissue $[19,20]$ after wounding, and also that the local concentration of HA in the wound decreases within a few days, when instead there is an increase in the concentration of sulphated glycosaminoglycans. It is also recognized that the time pattern for the increased HA concentration in the wound was substantially different in fetal and in adult wounds [21,22], thus explaining the different behaviour of tissue repair in adult and foetus [23].

Some authors reported that NaHA suppressed both the production of free radicals and the reduction of proteoglycan synthesis induced by IL-1beta in cultured bovine articular chondrocytes [24], and it has been demonstrated that NaHA of $900 \times 10^{3}$ average molecular weight suppressed both the reduction of proteoglycan synthesis induced by fibronectin fragments and subsequent cartilage degradation in vivo and in vitro [25]. HA moreover determine a reduction of cartilage degradation, it has been demonstrated that that expression of matrix metalloproteinase-3 (MMP-3) and IL-1beta were suppressed in synovium but not in cartilage tissues of the rabbit ACLT model by treatment with HA84, even though the suppressive effect on the articular cartilage destruction was still observed. This suggests that the suppression of the destruction of articular cartilage is due in part to the suppressive effect of NaHA on MMP-3 and IL-1beta expression in synovial tissue [26].

In this paper we have evaluated the possibility to stimulate the growth of cultured dermal fibroblasts creating a synergic effect with the addiction of non fragmented HA to PDRN.

\section{Material and Methods}

We tested "in vitro" the effects of a mixture of short chain polynucleotides $(7.5 \mathrm{mg} / \mathrm{ml})$ and a solution of hyaluronic acid sodium salt $(20 \mathrm{mg} / \mathrm{ml})$.

$\mathrm{Ha}$ and PN were from Mastelli srl (Sanremo, Italy). HA consists in pre filled syringe containing natural hyaluronic acid of biotechnological origin, with a concentration of $20 \mathrm{mg} / \mathrm{ml}$ and molecular weight of $1000 \mathrm{Kda}$. PN consists in pre filled syringe containing polynucleotides $7.5 \mathrm{mg} / \mathrm{ml}$.

The compounds were tested onto culture of human dermal fibroblasts.

\subsection{Cell Culture}

Dermal fibroblast was obtained from skin biopsies of young donor.

Cells was routinely grown in DMEM (Dulbecco Modi- 
fied Eagle Medium) (Lonza), with the addition of $10 \%$ of FCS (Foetal Calf serum) (Lonza) and (Penicillin Streptomycin, Sigma Aldrich) and maintained in modified atmosphere containing $5 \%$ of $\mathrm{CO}_{2}$ at $37^{\circ} \mathrm{C}$.

Cell for the experiment were from $4^{\text {th }}$ to $9^{\text {th }}$ passage in vitro.

Twenty-four hours after seeding, cells were treated for 3 days with: PN alone, Hyaluronic acid alone or a mixture of the 2 compounds at fixed doses and finally viability/proliferation was tested using the MTT assay.

\subsection{MTT Assay}

The MTT assay was used to measure cell viability. Basically, the intact mitochondria reduce the yellow dye tetrazolium salt (MTT) into blue formazan product. The amount of formazan, produced by the mitochondrial dehydrogenase activity, was measured at $570 \mathrm{~nm}$ with a microplate reader (Infinity F200, Tecan).

For these experiments dermal fibroblasts were seeded $\left(1 \times 10^{5}\right.$ cells/well) onto 96 -well plates and incubated for 3 days according with different experimental settings.

Assay was carried out according to Mosmann [27].

\subsection{Images}

Images of cell monolayer were collected with a Nikon TMS phase contrast microscope equipped with a digital camera (Digital sight DS-2Mv, Nikon). All shown images were acquired with a $20 \times$ objective.

\section{Result and Conclusion}

Proliferation and toxicity were evaluated with MTT assay.

Figure 1 shows the dose response effect $(0-1600$ $\mu \mathrm{g} / \mathrm{ml}$ ) of increasing doses of hyaluronic acid on proliferation and viability of cultured dermal fibroblasts.

After 3 days of treatment, MTT assay shows a slight increase of proliferation at the highest dose $(1600 \mu \mathrm{g} / \mathrm{ml})$

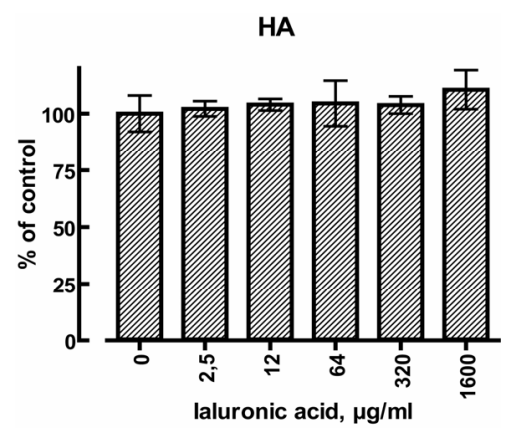

Figure 1. Dose response effect $(0-1600 \mu \mathrm{g} / \mathrm{ml})$ of increasing doses of hyaluronic acid on proliferation and viability of cultured dermal fibroblasts. MTT assay was performed after 3 days of treatment. Values represent the mean \pm S.D. of six wells. and highlights the absolute absence of toxicity of this compound at any proven dose.

Figure 2 shows the effect of increasing doses of a compound containing a mixture of $\mathrm{PN}$ at same time (3 days of treatment). Proliferative activity of fibroblasts increases in a dose-response manner with a maximal value reached at the doses of 64 and $320 \mu \mathrm{g} / \mathrm{ml}(+14 \%$ above control for both doses).

At the highest dose tested of $1600 \mu \mathrm{g} / \mathrm{ml}$ proliferation seems to return to control level.

From these two experiment we concluded that the optimal doses to stimulate dermal fibroblast proliferation was around $1 \mathrm{mg} / \mathrm{ml}$ for Hyaluronic acid while the optimal range for PN in absence of any sign of cellular toxicity was from 64 to $320 \mu \mathrm{g} / \mathrm{ml}$.

On these bases we have tested a mixture of these compound (PN and HA) to verify if the addition of Hyaluronic acid can exert a favorable effect further improving proliferative activity of dermal fibroblast treated with PN.

Figure 3 shows the results after 3 days of treatment. The comparison between treatments with PN with or without the addition of HA at the fixed dose of 1000 $\mu \mathrm{g} / \mathrm{ml}$ indicates that the latter could further stimulate the

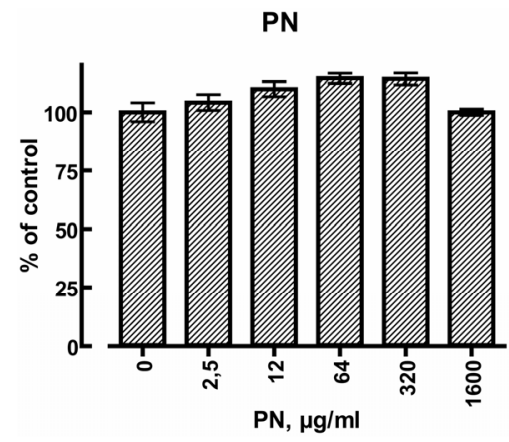

Figure 2. Dose response effect $(0-1600 \mu \mathrm{g} / \mathrm{ml})$ of increasing doses of polynucleotides on proliferation and viability of cultured dermal fibroblasts. MTT assay was performed after 3 days of treatment. Values represent the mean \pm S.D. of six wells.

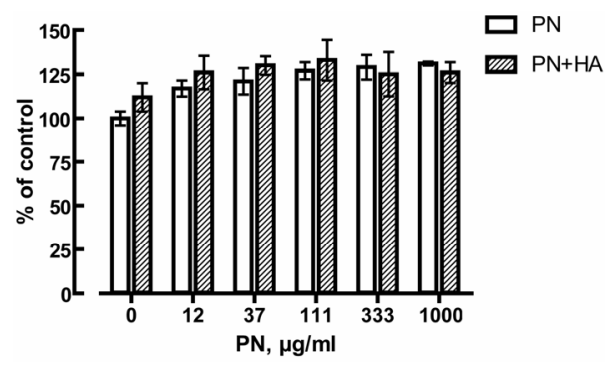

Figure 3. Dose response effect $(0-1600 \mu \mathrm{g} / \mathrm{ml})$ of increasing doses of polynucleotides, in the presence or in the absence of HA at the fixed dose of $1000 \mu \mathrm{g} / \mathrm{ml}$. MTT assay was performed after 3 days of treatment. Values represent the mean \pm S.D. of six wells. 
proliferation of dermal fibroblast and the best outcome is reached with $\mathrm{PN}$ in the range from $37 \mu \mathrm{g} / \mathrm{ml}$ to $111 \mu \mathrm{g} /$ $\mathrm{ml}$.

The representative images in Figure $\mathbf{4}$ are images with phase-contrast microscopy of fibroblasts cultures collected with a camera in the same condition of treatment summarized in the Figure 3 graph.

The column of images on the left shows PN only treated cells, while the right column shows cell cultures treated with the addition of HA $1 \mathrm{mg} / \mathrm{ml}$. Photos suggest the addition of hyaluronic acid appears to ameliorate the overall culture conditions, with an highest density of the cell culture obtained at the doses of PN mixture from 37 $\mu \mathrm{g} / \mathrm{ml}$ to $111 \mu \mathrm{g} / \mathrm{ml}$. In all tested conditions no changes

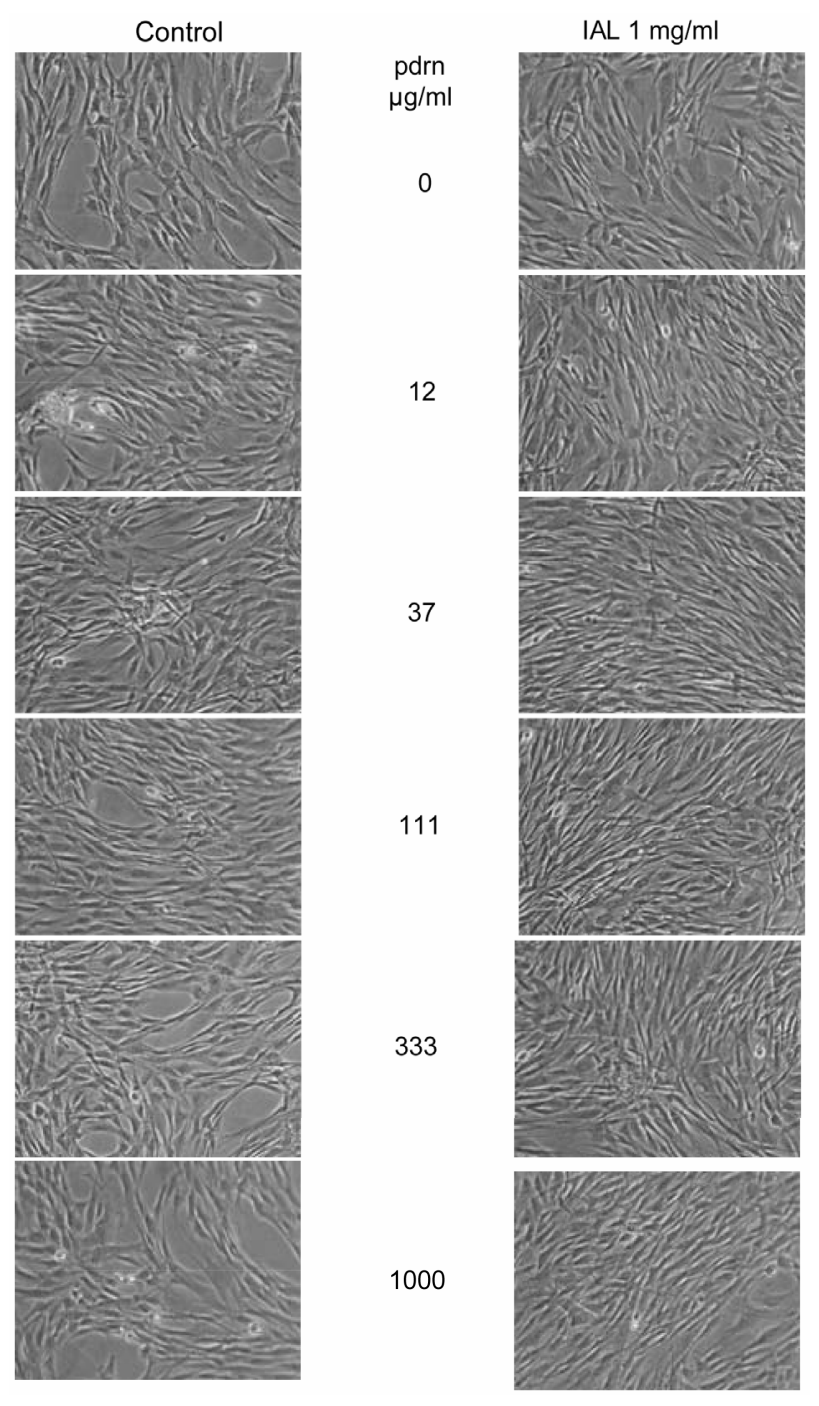

Figure 4. Representative images with phase-contrast microscopy of fibroblasts cultures collected with a camera in the same condition of treatment summarized in the Figure 3 graph. Different PN concentration was indicated in central colomn. Left column: only PN treated cells; right column: PN + HA treated cells. in cell morphology and signs of cellular toxicity were detected.

In conclusion the collected data show a different stimulating effect of PN in presence/absence of HA on cultured dermal fibroblasts. Indeed the increased cell growth obtained with $320 \mu \mathrm{g} / \mathrm{ml}$ of PN alone (14\%) is similar to those obtained at the dose of $64 \mu \mathrm{g} / \mathrm{ml}$ with the addiction of HA $1000 \mu \mathrm{g} / \mathrm{ml}$, thus indicating a sort of co-stimulating effect of HA.

The reason of this effect is actually unclear, we can argue a sort of clustering induced by HA comparable with that observed for adhesion and spreading of cultured cells.

Further investigations concerning HA derived PN co-stimulation could be helpful on development of bioactive fillers.

\section{REFERENCES}

[1] S. Thellung, T. Florio, A. Maragliano, G. Cattarini and G. Schettini, "Polydeoxyribonucleotides Enhance the Proliferation of Human Skin Fibroblasts: Involvement of A2 Purinergic Receptor Subtypes," Life Sciences, Vol. 64, No. 18, 1999, pp. 1661-1674. doi:10.1016/S0024-3205(99)00104-6

[2] P. Sini, A. Denti, G. Cattarini, M. Daglio, M. E. Tira and C. Balduini, "Effect of Polydeoxyribonucleotides on Human Fibroblasts in Primary Culture," Cell Biochemistry and Function, Vol. 17, No. 2, 1999, pp. 107-114. doi:10.1002/(SICI)1099-0844(199906)17:2<107::AID-C BF815>3.0.CO;2-\#

[3] O. Muratore, G. Cattarini, S. Gianoglio, E. L. Tonoli, S. C. Sacca, D. Ghiglione, D. Venzano, C. Ciurlo, P. B. Lantieri and G. C. Schito, "A Human Placental Polydeoxyribonucleotide (PDRN) May Promote the Growth of Human Corneal Fibroblasts and Iris Pigment Epithelial Cells in Primary Culture," New Microbiologica, Vol. 26, No. 1, 2003, pp. 13-26.

[4] S. Guizzardi, C. Galli, P. Govoni, R. Boratto, G. Cattarini, D. Martini, S. Belletti and R. Scandroglio, "Polydeoxyribonucleotide (PDRN) Promotes Human Osteoblast Proliferation: A New Proposal for Bone Tissue Repair," Life Sciences, Vol. 73, No. 15, 2003, pp. 1973-1983. doi:10.1016/S0024-3205(03)00547-2

[5] S. Belletti, J. Uggeri, R. Gatti, P. Govoni and S. Guizzardi, "Polydeoxyribonucleotide Promotes Cyclo-Butane Pyrimidine Dimer Repair in UVB-Exposed Dermal Fibroblasts," Photodermatology, Photoimmunology \& Photomedicine, Vol. 23, No. 6, 2007, pp. 242-249. doi:10.1111/j.1600-0781.2007.00320.x

[6] E. Raposio, C. Guida, R. Coradeghini, C. Scanarotti, A. Parodi, I. Baldelli, R. Fiocca and P. L. Santi, "In Vitro Polydeoxyribonucleotide Effects on Human Pre-Adipocytes," Cell Proliferation, Vol. 41, No. 5, 2008, pp. 739754. doi:10.1111/j.1365-2184.2008.00547.x

[7] P. Rubegni, G. De Aloe, C. Mazzatenta, L. Cattarini and M. Fimiani, "Clinical Evaluation of the Trophic Effect of Polydeoxyribonucleotide (PDRN) in Patients Undergoing 
Skin Explants. A Pilot Study," Current Medical Research \& Opinion, Vol. 17, No. 2, 2001, pp. 128-131.

[8] M. Lazzarotto, E. M. Tomasello and A. Caporossi, "Clinical Evaluation of Corneal Epithelialization after Photorefractive Keratectomy in Patients Treated with Polydeoxyribonucleotide (PDRN) Eye Drops: A Randomized, Double-Blind, Placebo-Controlled Trial," European Journal of Ophthalmology, Vol. 14, No. 4, 2004, pp. 284-289.

[9] L. Valdatta, A. Thione, C. Mortarino, M. Buoro and S. Tuinder, "Evaluation of the Efficacy of Polydeoxyribonucleotides in the Healing Process of Autologous Skin Graft Donor Sites: A Pilot Study," Current Medical Research \& Opinion, Vol. 20, No. 3, 2004, pp. 403-408. doi:10.1185/030079904125003116

[10] S. Guizzardi, D. Martini, B. Bacchelli, L. Valdatta, A. Thione, S. Scamoni, J. Uggeri and A. Ruggeri, "Effects of Heat Deproteinate Bone and Polynucleotides on Bone Regeneration: An Experimental Study on Rat," Micron, Vol. 38, No. 7, 2007, pp. 722-728. doi:10.1016/j.micron.2007.05.003

[11] M. Galeano, A. Bitto, D. Altavilla, L. Minutoli, F. Polito, M. Calo, P. Lo Cascio, F. Stagno D'Alcontres and F. Squadrito, "Polydeoxyribonucleotide Stimulates Angiogenesis and Wound Healing in the Genetically Diabetic Mouse," Wound Repair and Regeneration, Vol. 16, No. 2, 2008, pp. 208-217. doi:10.1111/j.1524-475X.2008.00361.x

[12] D. Altavilla, A. Bitto, F. Polito, H. Marini, L. Minutoli, V. Di Stefano, N. Irrera, G. Cattarini and F. Squadrito, "Polydeoxyribonucleotide (PDRN): A Safe Approach to Induce Therapeutic Angiogenesis in Peripheral Artery Occlusive Disease and in Diabetic Foot Ulcers," Cardiovascular \& Hematological Agents in Medicinal Chemistry, Vol. 7, No. 4, 2009, pp. 313-321. doi:10.2174/187152509789541909

[13] K. A. Jacobson and Z. G. Gao, "Adenosine Receptors as Therapeutic Targets," Nature Reviews Drug Discovery, Vol. 5, No. 3, 2006, pp. 247-264. doi:10.1038/nrd1983

[14] B. P. Toole, "Hyaluronan in Morphogenesis," Journal of Internal Medicine, Vol. 242, No. 1, 1997, pp. 35-40. doi:10.1046/j.1365-2796.1997.00171.x

[15] P. H. Weigel, V. C. Hascall and M. Tammi, "Hyaluronan Synthases," The Journal of Biological Chemistry, Vol. 272, No. 22, 1997, pp. 13997-14000. doi:10.1074/jbc.272.22.13997

[16] N. Itano, T. Sawai, F. Atsumi, O. Miyaishi, S. Taniguchi, R. Kannagi, M. Hamaguchi and K. Kimata, "Selective Expression and Functional Characteristics of Three Mammalian Hyaluronan Synthases in Oncogenic Malignant Transformation," The Journal of Biological Chemistry, Vol. 279, No. 18, 2004, pp. 18679-18687. doi:10.1074/jbc.M313178200

[17] W. Knudson, C. Biswas and B. P. Toole, "Interactions between Human Tumor Cells and Fibroblasts Stimulate Hyaluronate Synthesis," Proceedings of the National Academy of Sciences of the United States of America, Vol. 81, No. 21, 1984, pp. 6767-6771. doi:10.1073/pnas.81.21.6767
[18] L. Udabage, G. R. Brownlee, S. K. Nilsson and T. J. Brown, "The Over-Expression of HAS2, Hyal-2 and CD44 Is Implicated in the Invasiveness of Breast Cancer," Experimental Cell Research, Vol. 310, No. 1, 2005, pp. 205-217. doi:10.1016/j.yexcr.2005.07.026

[19] O. Oksala, T. Salo, R. Tammi, L. Hakkinen, M. Jalkanen, P. Inki and H. Larjava, "Expression of Proteoglycans and Hyaluronan during Wound Healing," Journal of Histochemistry \& Cytochemistry, Vol. 43, No. 2, 1995, pp. 125135. doi: $10.1177 / 43.2 .7529785$

[20] P. H. Weigel, G. M. Fuller and R. D. LeBoeuf, “A Model for the Role of Hyaluronic Acid and Fibrin in the Early Events during the Inflammatory Response and Wound Healing," Journal of Theoretical Biology, Vol. 119, No. 2, 1986, pp. 219-234. doi:10.1016/S0022-5193(86)80076-5

[21] M. T. Longaker, E. S. Chiu, N. S. Adzick, M. Stern, M. R. Harrison and R. Stern, "Studies in Fetal Wound Healing. V. A Prolonged Presence of Hyaluronic Acid Characterizes Fetal Wound Fluid," Annals of Surgery, Vol. 213, No. 4, 1991, pp. 292-296. doi:10.1097/00000658-199104000-00003

[22] M. T. Longaker, E. S. Chiu, M. R. Harrison, T. M. Crombleholme, J. C. Langer, B. W. Duncan, N. S. Adzick, E. D. Verrier and R. Stern, "Studies in Fetal Wound Healing. IV. Hyaluronic Acid-Stimulating Activity Distinguishes Fetal Wound Fluid from Adult Wound Fluid," Annals of Surgery, Vol. 210, No. 5, 1989, pp. 667-672. doi:10.1097/00000658-198911000-00016

[23] R. Tammi, S. Pasonen-Seppanen, E. Kolehmainen and M. Tammi, "Hyaluronan Synthase Induction and Hyaluronan Accumulation in Mouse Epidermis Following Skin Injury," Journal of Investigative Dermatology, Vol. 124, No. 5, 2005, pp. 898-905. doi:10.1111/j.0022-202X.2005.23697.x

[24] K. Fukuda, H. Dan, M. Takayama, F. Kumano, M. Saitoh and S. Tanaka, "Hyaluronic Acid Increases Proteoglycan Synthesis in Bovine Articular Cartilage in the Presence of Interleukin-1," Journal of Pharmacology and Experimental Therapeutics, Vol. 277, No. 3, 1996, pp. 1672-1675.

[25] G. A. Homandberg, F. Hui, C. Wen, K. E. Kuettner and J. M. Williams, "Hyaluronic Acid Suppresses Fibronectin Fragment Mediated Cartilage Chondrolysis: I. In Vitro," Osteoarthritis Cartilage, Vol. 5, No. 5, 1997, pp. 309-319. doi:10.1016/S1063-4584(97)80035-0

[26] K. Takahashi, R. S. Goomer, F. Harwood, T. Kubo, Y. Hirasawa and D. Amiel, "The Effects of Hyaluronan on Matrix Metalloproteinase-3 (MMP-3), Interleukin-1Beta (IL-1Beta), and Tissue Inhibitor of Metalloproteinase-1 (TIMP-1) Gene Expression during the Development of Osteoarthritis," Osteoarthritis Cartilage, Vol. 7, No. 2, 1999, pp. 182-190. doi:10.1053/joca.1998.0207

[27] T. Mosmann, "Rapid Colorimetric Assay for Cellular Growth and Survival: Application to Proliferation and Cytotoxicity Assays," Journal of Immunological Methods, Vol. 65, No. 1-2, 1983, pp. 55-63. doi:10.1016/0022-1759(83)90303-4 